\title{
Geo-Sciences
}

\section{Assessment of spectral indexes for estimating soil water content in the Brazilian Pantanal}

\author{
Victor Hugo de Morais Danelichen $\left.{ }^{(}{ }^{(}\right)$, Osvaldo Alves Pereira' ${ }^{1}$, \\ Marcelo Sacardi Biudes"(i), José de Souza Nogueira"I(1) \\ ' Universidade de Cuiabá, Cuiabá, MT, Brazil \\ "Universidade Federal de Mato Grosso, Cuiabá, MT, Brazil
}

\begin{abstract}
The Pantanal is the largest floodplain of the globe occupying $138,183 \mathrm{~km}^{2}$ in Brazil. The fundamental ecological factor of interaction between the Pantanal ecosystems is the flooding regime. Connected to properties of the soil-plant-atmosphere system, knowledge on the soil water content becomes increasingly necessary. The high temporal and spatial variability of water content in the soil caused by the vast heterogeneity of soil texture, vegetation, topography and climate makes it a difficult physical variable to be measured. However, its spatial and temporal variability can be determined by recent modern techniques of remote sensing based on data obtained by microwave or infrared sensors. Thus, the aim of this study was to evaluate the accuracy of vegetation and soil water indexes through satellite images from Landsat 5 in the northern Brazilian Pantanal. The study was conducted in a pasture, experimental site in the Northern Pantanal in Mato Grosso state. Soil moisture was measured using a TDR probe installed at $10 \mathrm{~cm}$ depth in the period from 2009 to 2011. For comparison, spectral indexes and the surface temperature provided by Geological Survey (USGS) were used, these indexes are derived from bands ratios of satellite reflectance products Landsat $5 \mathrm{TM}$. The data evaluation was performed using some indicators: accuracy - Willmott index, Root Mean Square Error and the Mean Absolute Error. This study demonstrated that the application of remote sensing in the management of water resources is very promising. The indexes correlated with soil moisture measurement. Among the soil water indexes the NBR-2 showed related to soil moisture measurement. For both types of soils EVI had the highest determination coefficient, lowest errors and highest Willmott's index of agreement.
\end{abstract}

Keywords: Pasture; Remote sensing; Landsat 5 


\section{INTRODUCTION}

With approximately $250,000 \mathrm{~km}^{2}$, the Pantanal is the largest floodplain of the globe (ANDRADE et al., 2012). The fundamental ecological factor and main moderator of force interaction between the Pantanal ecosystems is the flooding regime (CATIAN et al., 2017). Due to the expansion of the agricultural frontier and of agricultural activities increase the Pantanal has been considered a fragile ecosystem, as a result of such activities, the rivers and soils of this biome are affected by siltation of its banks (BAZZO et al., 2012).

Much of the Pantanal (92\%) is formed by hydromorphic soils, reflecting poor drainage and prone to prolonged and periodic flooding. The Pantanal soil geologically were developed from sandy unconsolidated sediments, clay and organic, deposited during the Quaternary period (CORINGA et al., 2012). Constituting the formation of the Pantanal the much of its length is formed by sediments deposited in the Cenozoic detrital deposits of waste and surrounding highlands of Pleistocene, and the plain deposits of flooding of rivers, which occurred in the Holocene (FERNANDES et al., 2007).

Closely linked to the properties of the soil-plant-atmosphere system, knowledge on the water content in soil becomes increasingly necessary (CREMON et al., 2014). Due to the water system together with its geomorphology, the Pantanal has specific soil characteristics, soil formation with different characteristics that should be considered in its use (CORINGA et al., 2012). The gleyzation and plintization are the most common pedogenic processes in these soils, which are responsible for the gray colors for the most part of your profile. Because of these processes, the formation of the Pantanal presents great diversity of soils, as Planosols, Plinthosols, Gleysols Cambisols Fluvic, Neossolos, Luvisols and Vertisols (COUTO \& OLIVEIRA, 2010). Despite the simple physical concept of soil moisture, its determination presents difficulties in obtaining representative 
values due to the spatial and temporal variability of soil physical properties (BAZZO et al., 2012).

However, the spatial and temporal variability of soil moisture can be determined by recent modern techniques of remote sensing (PENG et al., 2017). Thus, many indices have been proposed in the literature to estimate the water content in the soil (GAO, 1996; FORD et al., 2019). McFeeters (1996) developed the normalized difference water index (NDWI). Gao (1996) proposed a different NDWI used to estimate the water content in the vegetation canopy. Although NDWI of McFeeters and Gao have the same terminology, the concepts of the two are different complements. Thus, the aim of this study was to evaluate the accuracy of vegetation and soil water indexes through satellite images from Landsat 5 - TM in the north of the Brazilian Pantanal.

\section{MATERIAL AND METHODS}

\subsection{Site description}

The study was conducted on one experimental site in the Northern Pantanal in Mato Grosso (Figure 1). This area has an average annual temperature of $26.2^{\circ} \mathrm{C}$, annual rainfall between 1300 and $1400 \mathrm{~mm}$ and a well-defined dry season, from May to September, and a rainy season from October to April (MACHADO et al. 2015). The experimental site was located at Fazenda Miranda (FMI) $\left(15^{\circ} 43^{\prime} 53.65^{\prime \prime} \mathrm{S}, 56^{\circ}\right.$ 4' 18.88" W and altitude of 157 m) in the city of Cuiabá, Mato Grosso State, Brazil. The vegetation of this experimental site was a non-native grassland (Brachiaria humidicola) and the soil was classified as Plinthosol (SEPLAN, 2001, BIUDES, 2013). 
Figure 1 - Study area located on Miranda Farm (FMI)

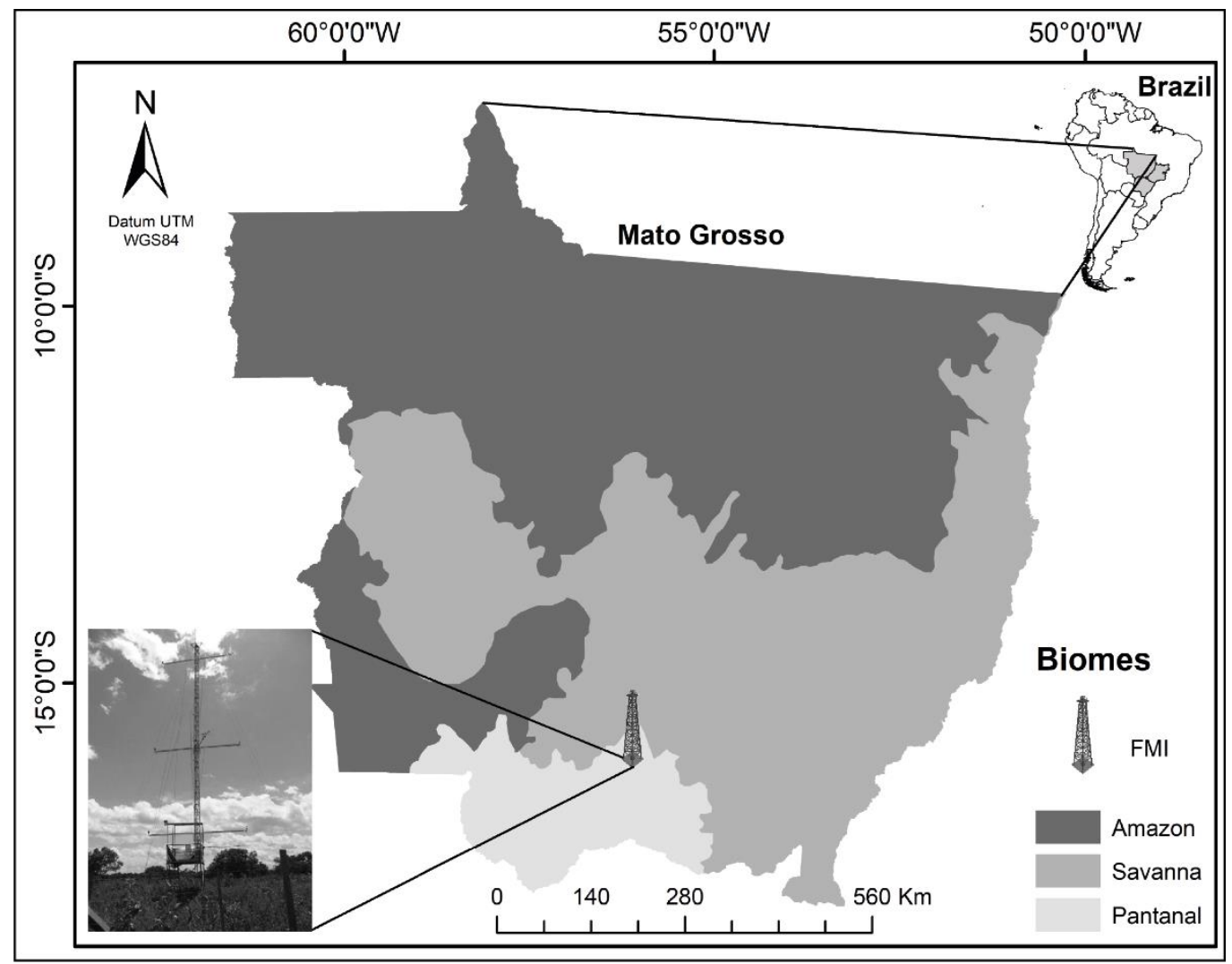

\subsection{Measurement of soil water content}

The soil water content was measured from May 2009 to September 2011 at the FMI by a time-domain reflectometer (CS-616, Campbell Scientific, Inc., Logan, UT, USA) installed at $10 \mathrm{~cm}$ depth in two types of soil (lateritic and sandy), and connected to a datalogger (CR1000, Campbell Scientific, Inc., Logan, UT, USA), which has scan every 30 seconds and storage every 30 minutes, and then reorganized on a monthly scale.

\subsection{Remote sensing data}

For comparison with the soil water content measured, spectral indices and radiometric surface temperature with a spatial resolution of $30 \mathrm{~m}$ (Landsat 5 satellite), supplied by the Center Science Processing Architecture (ESPA) (http://espa.cr.usgs.gov/) of the US Geological Survey (USGS) were used (Table 1). 
These indexes are derived from bands ratios of satellite reflectance products Landsat 5 TM, are generated from a specialized software called Landsat Ecosystem Disturbance Adaptive Processing System (LEDAPS). LEDAPS was originally developed by the National Aeronautics and Space Administration (NASA). The software applies the routines of atmospheric correction for level 1 Landsat TM or ETM + data (MASEK et al., 2006). The satellite Landsat 5 was launched on 1 March 1984 and works in equatorial orbit at $705 \mathrm{~km}$ altitude. The sensor TM (Thematic Mapper) on board the satellite makes the imaging of the earth's surface producing images with $185 \mathrm{~km}$ wide on the ground spatial resolution of 30 meters and 7 spectral bands. The satellite revisit time to image the same portion of the land is 16 days. In this study 46 images of the Landsat 5 satellite reflectance were used.

In this work, we admit that the burning indexes (NBR and NBR-2) are referred to as water deficit indicators. In the same way, we admit the spectral index (NDWI to NDMI) proposed by Gao et al. (1996) as a reference acronym by the USGS (U.S. Geological Survey) for more current discussion in the scientific literature (Table 1). The monthly precipitation (V7 product 3B43) was obtained in Distributed Active Archive System (DAAC) (http://disc.sci.gsfc.nasa.gov/precipitation/tovas/) by satellite Tropical Rainfall Measuring Mission (TRMM).

Table 1 - Spectral indexes for vegetation estimation and soil water content (NDVI, EVI, SAVI, MSAVI, NDMI, NBR and NBR-2)

\begin{tabular}{ll}
\hline Spectral indexes & Authors \\
\hline Normalized Difference Vegetation Index (NDVI) & Rouse et al., 1973 \\
Enhanced Vegetation Index (EVI) & Huete et al., 1997 \\
Soil Adjusted Vegetation Index (SAVI) & Huete, 1988 \\
Modified Soil Adjusted Vegetation Index (MSAVI) & Qi et al., 1994 \\
Normalized Difference Moisture Index (NDMI) & Gao et al., 1996 \\
Normalized Burn Ratio (NBR) & Lopez Garcia \& Caselles, 1991 \\
Normalized Burn Ratio 2 (NBR2) & Miller \& Thode, 2007 \\
\hline
\end{tabular}


The performance of the indices in relation to the soil water content measured was analyzed by the Willmott's index of agreement (d), Root Mean Square Error (RMSE) and the Mean Absolute Error (MAE) (WILLMOTT et al., 2012).

The accuracy is related to the removal of the estimated values on the observed. Mathematically this approach is given by a designated concordance index can be widely applied to model comparison (WILLMOTT et al., 1985). Their values range from zero, with no agreement, to 1, with perfect agreement.

$$
d=1-\left[\sum\left(P_{i}-O_{i}\right)^{2} / \sum\left(\left\|P_{i}-O\right\|+\left\|O_{i}-O\right\|\right)^{2}\right]
$$

where $P_{i}$ is the estimated value, $O_{i}$ the observed value and $O$ the average of the observed values.

The RMSE indicates how the model fails to estimate the variability of measurements around the mean and measures the change in the estimated values around the measured values (WILLMOTT AND MATSUURA, 2005). The lower RMSE limit is 0 , which means that there is full compliance between model estimates and measurements.

$$
R M S E=\sqrt{\frac{\sum\left(P_{i}-O_{i}\right)^{2}}{n}}
$$

The MAE indicates the distance (deviation) absolute average of the estimated values on the measured values. Ideally, the values of the MAE and the RMSE were close to zero (WILLMOTT AND MATSUURA, 2005).

$$
M A E=\sum \frac{\left|P_{i}-O_{i}\right|}{n}
$$




\section{RESULTS AND DISCUSSION}

The soil water content measured increased between the months of August and December, for sandy and lateritic soils, following the rainfall and influencing the surface temperature with maximum values in the rainy season (Figure 2 ). This pattern indicates the seasonal and spatial variability of the rainfall regime. This dynamic soil temperature and humidity in the study area was observed by Biudes et al. (2015) and Danelichen et al. (2016).

Figure 2 - Soil moisture measured monthly at Miranda Farm (FMI) for the sandy soil and laterite, in contrast to the surface temperature $(-A)$ and precipitation estimated by the TRMM (-B). Gray background stripes correspond to the rainy season

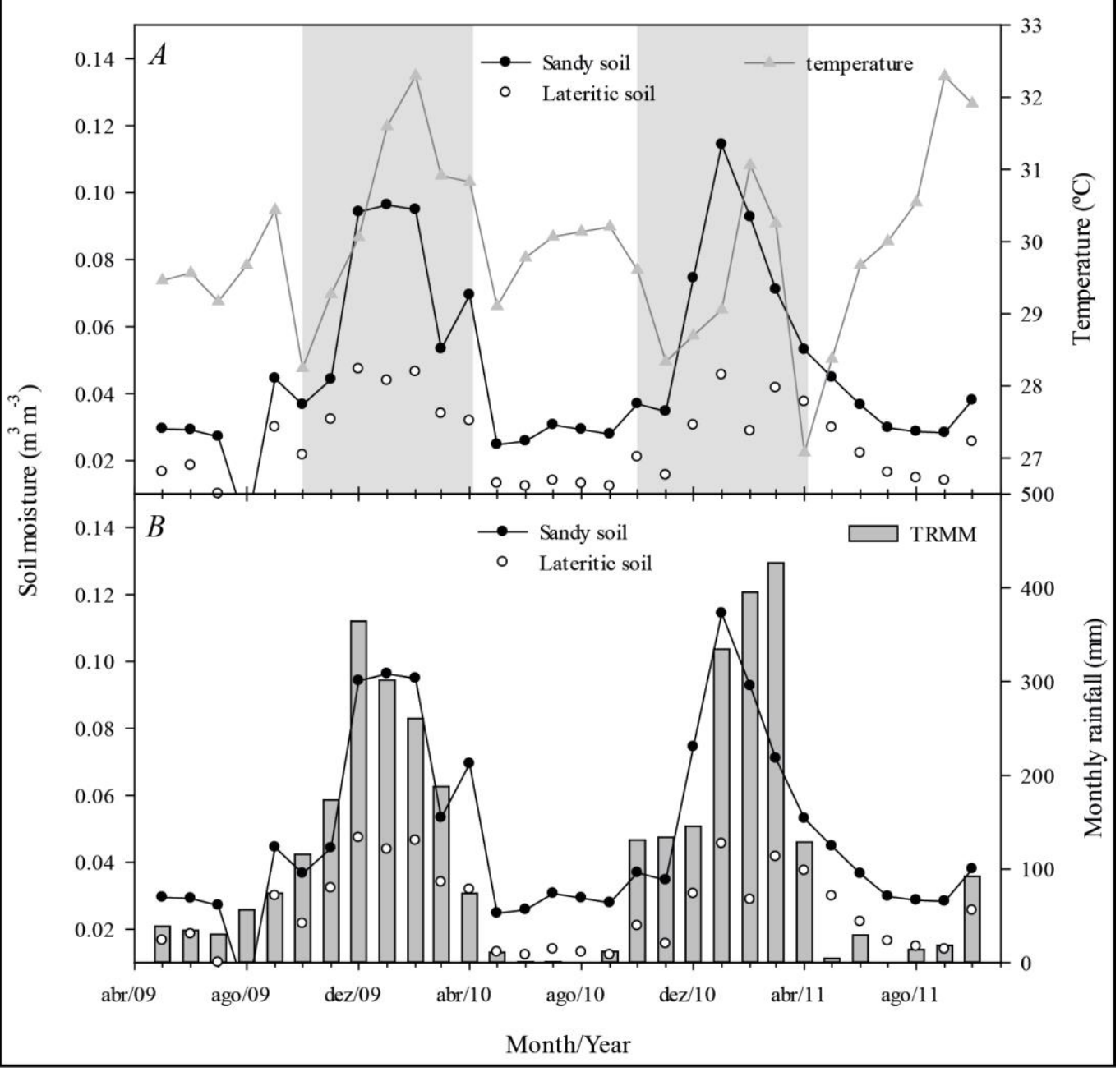

Ci. e Nat., Santa Maria, v.43, e48, 2021 
The decrease and increase in soil water content are related to the period of soil drying and wetting, respectively, depending on the local precipitation (Figure 2). Daily estimates of the TRMM satellite had relationship with soil moisture (Table 2).

Table 2 - Pearson correlation matrix between soil moisture measurement (sandy soil and laterite), vegetation indexes (EVI, NDVI, SAVI and MSAVI), soil water indexes (NDMI, NBR and NBR-2), land surface temperature (LST), daily precipitation (TRMM daily) and monthly precipitation (TRMM monthly) of Miranda Farm (* $p<0.05, * \star p<0.001$ )

\begin{tabular}{|c|c|c|c|c|c|c|c|c|c|c|c|c|}
\hline & Sand. & Lat. & EVI & MSAVI & NBR & NBR2 & NDMI & NDVI & SAVI & LST & $\begin{array}{l}\text { TRMM } \\
\text { day }\end{array}$ & $\begin{array}{l}\text { TRMM } \\
\text { mon }\end{array}$ \\
\hline Sand. & 1 & & & & & & & & & & & \\
\hline Lat. & $0.92^{* *}$ & 1 & & & & & & & & & & \\
\hline $\mathrm{EVI}$ & $0.46^{* *}$ & $0.58^{* *}$ & 1 & & & & & & & & & \\
\hline MSAVI & -0.28 & -0.17 & 0.26 & 1 & & & & & & & & \\
\hline NBR & -0.24 & -0.15 & 0.03 & $0.57^{* *}$ & 1 & & & & & & & \\
\hline NBR2 & $0.38^{*}$ & $0.46^{* *}$ & $0.78^{* *}$ & 0.24 & 0.20 & 1 & & & & & & \\
\hline NDMI & $0.37^{*}$ & $0.45^{* *}$ & $0.73^{* *}$ & $0.35^{* *}$ & 0.19 & $0.87^{* *}$ & 1 & & & & & \\
\hline NDVI & $0.45^{* *}$ & $0.57^{* *}$ & $0.72^{* *}$ & 0.21 & 0.21 & $0.90^{* *}$ & $0.74^{* *}$ & 1 & & & & \\
\hline SAVI & $0.32^{*}$ & $0.47^{* *}$ & $0.69^{* *}$ & $0.51^{* *}$ & $0.28^{*}$ & $0.65^{* *}$ & $0.64^{* *}$ & $0.68^{* *}$ & 1 & & & \\
\hline LST & 0.18 & 0.18 & -0.07 & $-0.36^{* *}$ & -0.07 & -0.07 & -0.22 & 0.01 & -0.13 & 1 & & \\
\hline $\begin{array}{l}\text { TRMM } \\
\text { day }\end{array}$ & 0.51 & 0.41 & 0.29 & -0.20 & 0.48 & 0.45 & 0.41 & 0.56 & -0.08 & $0.91^{* *}$ & 1 & \\
\hline $\begin{array}{l}\text { TRMM } \\
\text { mon }\end{array}$ & -0.36 & -0.23 & -0.13 & 0.18 & -0.03 & -0.36 & -0.03 & $-0.46^{*}$ & 0.22 & $-0.45^{*}$ & -0.64 & 1 \\
\hline
\end{tabular}

Featuring well-defined seasons, in the Midwest region where the experimental site is located, the summer is characterized by high soil moisture and drier winter. From April the frontal systems start to act more frequently in the winter period in the southern hemisphere, favoring the advance of cold fronts to the south of Brazil (Gevaerd \& Freitas, 2006). 
Soil moisture showed a strong correlation in different soils (sandy and laterite), in both dry and rainy seasons, along the entire study period (Table 2). In the pasture area the sandy soil showed a small difference in soil moisture, which was only $2 \%$ higher than in the lateritic soil. This difference is expected because the land cover change causes physical and chemical changes in the soil (Cremon et a., 2014). In the pasture area, soil density tends to be higher in the soil surface layer, due to the influence of management factors such as effect of the pressure applied, soil texture and porosity (CREMON et al., 2014).

Microporosity decreases in these soils with increasing depth (BEZERRA et al., 2013). Collares et al. (2006) reported that with the increase of bulk density there is a redistribution of pore sizes, and this process tends to occur with reduced macroporosity and increased soil microporosity until the values of soil microporosity approach the values of total porosity.

All indexes were affected by local seasonality with maximum peaks in the rainy season and low values in the dry season (Figure 3). The vegetation and soil water indexes were affected by the water content measured in soil having correlations ( $p$-value $<0.05)$ in different types of soil (Table 2$)$. The EVI $\left(r_{\text {sandy }}=0.46\right.$ with sandy soil and $r_{\text {lateritic }}=0.58$ with lateritic soil) was strongly related to soil moisture ( $p$-value $<0.001)$.

The ratio of EVI and other vegetation indices with the surface water content is not strange nor new, given that the bands 1, 2, 3 and 4 of the Landsat 5, used for the calculation of these indexes, cover part of spectral signature of clean water (clear water) and cloudy water (turbid water). Sakamoto et al. (2007) used EVI, LSWI and the difference between them (DVEL) based on MODIS reflectances to map the Cambodian flood periods. These authors compared their results with RADARSAT radar products, results derived from Landsat 5 and hydrological data, and obtained coefficients of determination $\left(R^{2}\right)$ greater than 0.89 with Landsat products and above 0.77 with RADARSAT data. 
Figure 3 - Soil moisture measurement (sandy and lateritic soil - loco measurement) at Miranda Farm (FMI) in contrast to the vegetation indexes (EVI, MSAVI, NDVI and SAVI A) and soil water indexes (NDMI, NBR-2 and NBR -B) for the entire study period. Light gray stripes correspond to the rainy season

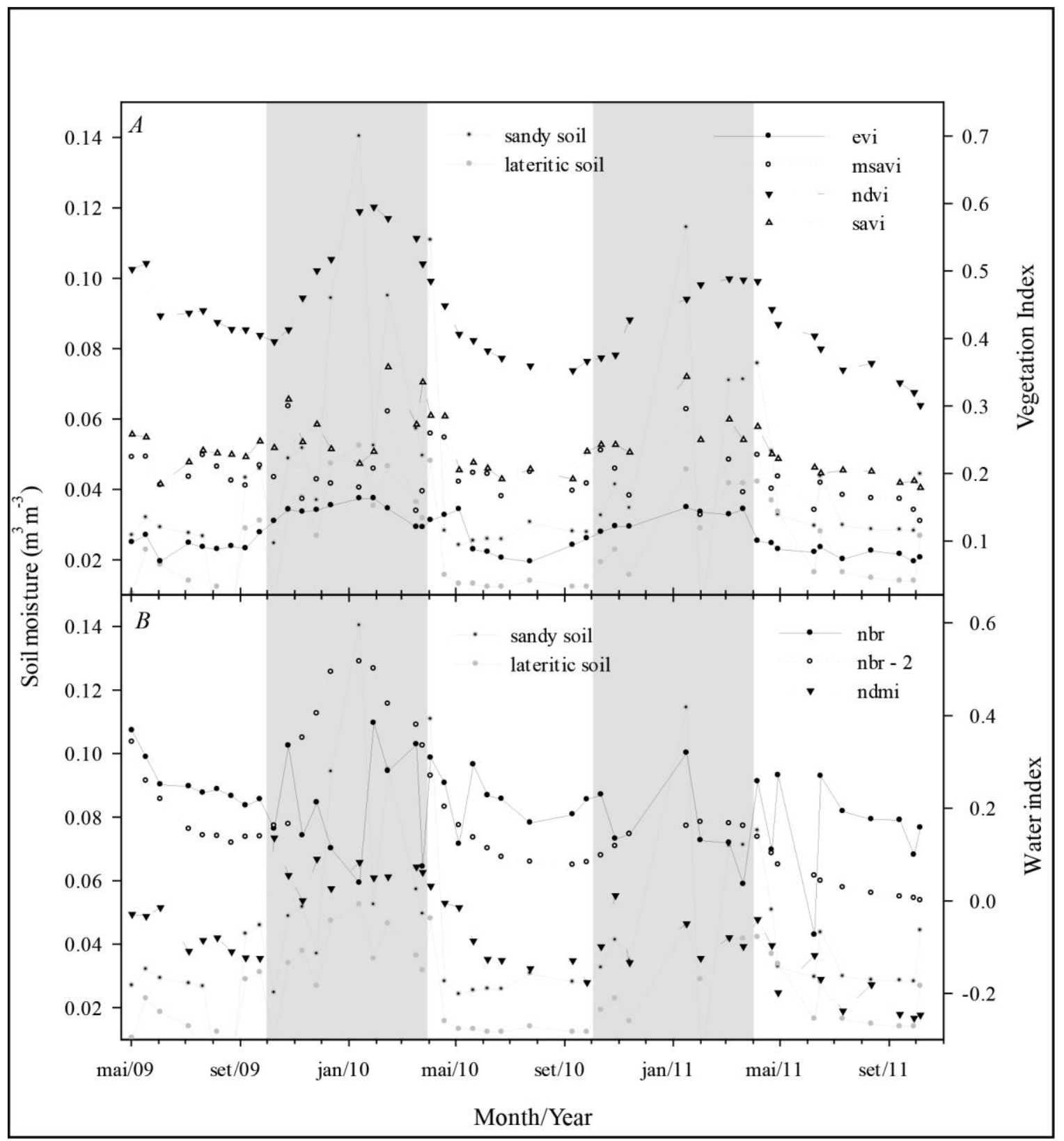

In FMI the NDVI and SAVI vegetation indexes also showed correlated with soil moisture measured, for NDVI $\left(r_{\text {sandy }}=0.45\right.$ and $\left.r_{\text {lateritic }}=0.57\right)$ and the SAVI $\left(r_{\text {sandy }}=\right.$ 0.32 and $\left.r_{\text {lateritic }}=0.47\right)$ between the soil water indexes, the NBR-2 $\left(r_{\text {sandy }}=0.38\right.$ and 
$\left.r_{\text {lateritic }}=0.46\right)$ and NDMI $\left(r_{\text {sandy }}=0.37\right.$ and $\left.r_{\text {lateritic }}=0.45\right)$ had the highest correlations (Table 2).

Interestingly, the NBR-2 index was correlated with soil moisture measured in two types of soil (Table 2). This index is the ratio of the sums of the bands 5 and 7 (approximately the range 1.5 to $2.5 \mu \mathrm{m}$ ). In Landsat 5 satellite, these bands, different from NDMI, which has the bands 4 and 5 in its computation, cover the two amplitudes of the spectral signature of grassy vegetation (GAO et al., 1996).

The NDMI covering the two largest amplitudes for spectral signature of the dry grassy vegetation, 4 and 5 bands, correlated with the water content in the soil measured in pasture area (Table 2$)$. The band $4(0.76$ to $0.90 \mu \mathrm{m})$ of the Landsat-5 corresponds to the NIR band and the band $5(1.55$ to $1.75 \mu \mathrm{m})$ to the SWIR. These wavelengths were selected to (1) maximize the typical reflectance of water bodies; (2) minimize the low reflectance NIR by water bodies and (3) take advantage of highreflectance NIR by surface vegetation and soil characteristics. When computed by sensors that obtain NDMI, multispectral images have positive values for water bodies and negative values or zero for soils and terrestrial vegetation, which effectively eliminates the terrestrial vegetation and soil information withholding information from bodies of water for analysis (PEREIRA et al., 2018).

Serrano et al. (2000), comparing the reflectance of 23 types of vegetation of chaparral plant communities in California (USA) at different stages of phenology and structural and canopy cover, found that NDMI responds not only to structure and coverage, but also to the vegetation water content, at landscape scale. Similarly, Chen et al. (2005) found a high correlation coefficient $\left(R^{2}\right)$ for soybean and corn in lowa (USA) comparing the NDMI with the water content at different stages of growth of vegetation.

Results of studies involving simulations of the boundary layer and energy balance of forests and pastures in regions of the Pantanal and the Amazon region indicate that the development of pasture changes the height of the nocturnal boundary layer, causing the decrease in latent heat flux and increase in sensible 
heat flux, which causes a complex change in local and regional patterns, reducing precipitation and evaporation (20 to 30\%), increasing the air temperature (from 0.6 to $2.0^{\circ} \mathrm{C}$ ) and intensification of drought (NOBRE et al., 1996). When comparing soil water content with spectral indexes, EVI presents higher correlations and lower errors (Table 3).

Table 3 - The performance of the indices in relation to the soil water content measured (lateritic soil and sandy soil). The Willmott's index of agreement (d), Correlation (r), Root Mean Square Error (RMSE) and the Mean Absolute Error (MAE)

\begin{tabular}{lllllllll}
\hline & \multicolumn{3}{c}{ Lateritic soil } & \multicolumn{5}{c}{ Sandy soil } \\
\hline & MAE & RMSE & $d$ & $r$ & MAE & RMSE & $d$ & $r$ \\
EVI & 0.09 & 0.09 & 0.58 & 0.61 & 0.07 & 0.08 & 0.77 & 0.51 \\
MSAVI & 0.17 & 0.18 & 0.38 & -0.07 & 0.15 & 0.16 & 0.55 & -0.24 \\
NBR & 0.18 & 0.20 & 0.32 & -0.16 & 0.16 & 0.19 & 0.48 & -0.17 \\
NBR2 & 0.16 & 0.21 & 0.32 & 0.54 & 0.15 & 0.20 & 0.50 & 0.54 \\
NDMI & 0.09 & 0.13 & 0.12 & 0.46 & 0.11 & 0.14 & 0.17 & 0.39 \\
NDVI & 0.41 & 0.42 & 0.20 & 0.59 & 0.40 & 0.40 & 0.32 & 0.50 \\
SAVI & 0.21 & 0.22 & 0.34 & 0.45 & 0.20 & 0.20 & 0.50 & 0.25 \\
\hline
\end{tabular}

In FMI the EVI, NDVI and NBR-2 indexes showed higher coefficients of determination for the two soil types (sandy and laterite). Among the indexes, EVI showed higher performance, overestimating soil moisture in the lateritic soil by $36 \%$ (Figure 4). These results are consistent with studies conducted by Ahmad \& Bastiaanssen (2003) and Bezerra et al. (2013), who used the SEBAL to estimate the evaporative fraction with bases on Landsat 5 satellite reflectances relating to soil moisture obtained in cotton crops in Brazil, wheat and rice in Pakistan. The authors found an RMSE greater than $0.05 \mathrm{~m}^{3} \mathrm{~m}^{-3}$. Ahmad \& Bastiaanssen (2003) found that these errors tend to increase systematically with the absolute values, such as evaporative fraction, which showed similar values to those found by Scott et al. (2003) in irrigated soils in the Lerma-Chapala basin in Mexico. 
Figure 4 - Regression of soil moisture measured at FMI in contrast to the vegetation indexes, soil water indexes and surface temperature. Equations with index 1 indicate relationship with variables in contrast to moisture in the sandy soil, while equations with index 2 indicate list of variables with moisture in the laterite soil

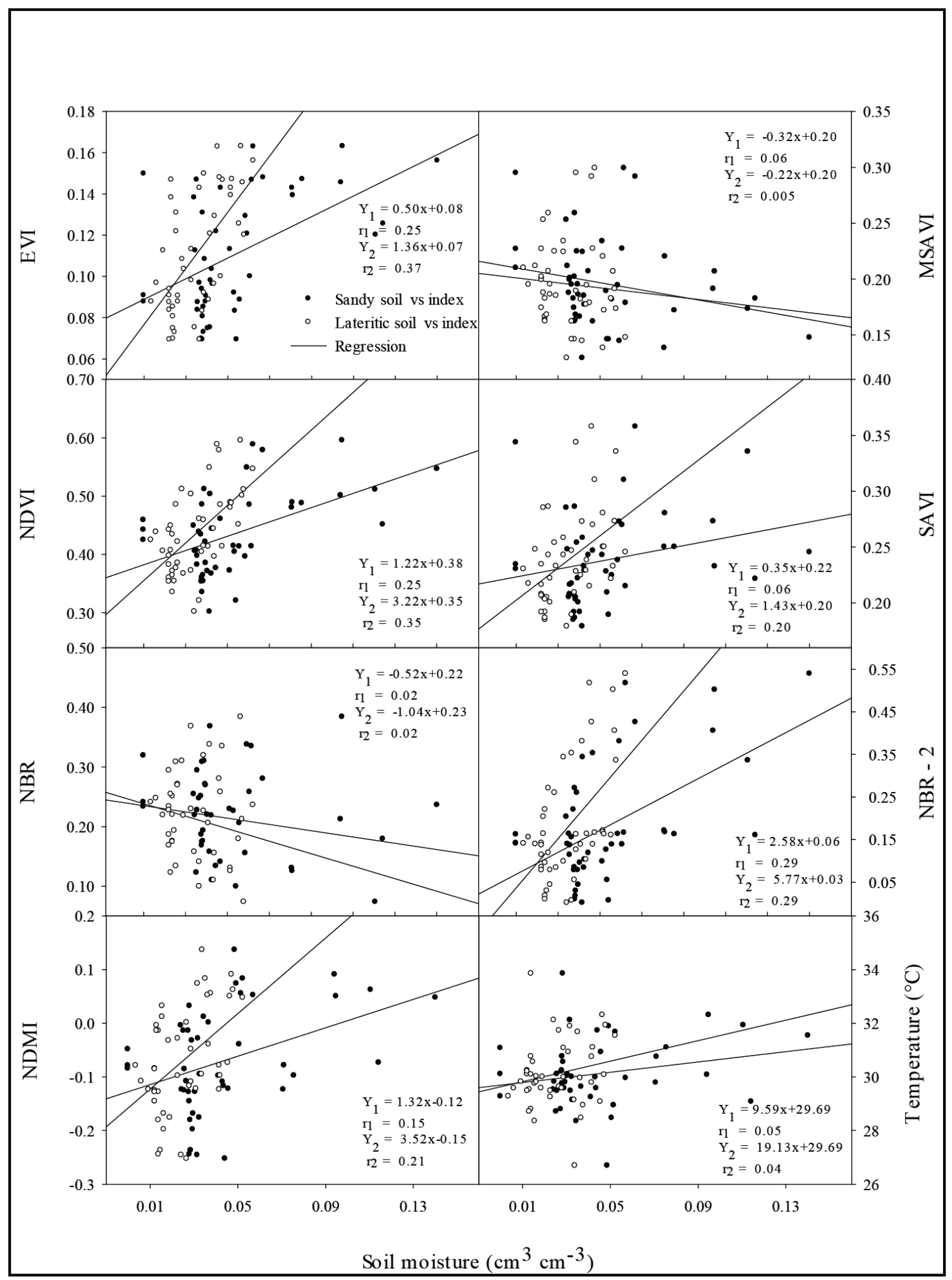




\section{CONCLUSIONS}

1. This study demonstrated that the application of the use of remote sensing products in the management of water resources is very promising. However, only proper use, awareness of limitations and correct interpretation of remote sensing data can facilitate water management and planning operations.

2. The decrease and increase in soil water indexes were related to the periods of soil drying and moistening, depending on local precipitation. The EVI and NDVI correlated with soil moisture measurement. Among the soil water indexes the NBR-2 showed related to soil moisture.

3. For both types of soils, the EVI had the highest coefficient of determination, lowest errors and highest Willmott's index of agreement.

\section{REFERENCES}

Ahmad, M.; Bastiaanssen, W. G. M. Retrieving soil moisture storage in the unsaturated zone using satellite imagery and bi-annual phreatic surface fluctuations. Irrigation and Drainage Systems, v.17, p.141-161, 2003.

Andrade, R. G.; Sediyama, G. C.; Paz, A. R.; Lima, E. P.; Facco, A. G. Geotecnologias aplicadas à avaliação de parâmetros biofísicos do Pantanal. Pesquisa Agropecuária Brasileira, v.47, n.9, p.1227-1234, 2012.

Bazzo, J. C.; Freitas, D. A. F.; Silva, M. L. N.; Cardoso, E. V.; Santos, S. A. Aspectos geofísicos e ambientais do Pantanal da Nhecolândia. Revista de Geografia. v. 29, p.141-151, 2012.

Bezerra, B. G.; Santos, C. A. C.; Silva, B. B.; Perez-marin, A. M.; Bezerra, M. V. C.; Bezerra, J. R. C.; Rao, T. V. R. Estimation of soil moisture in the root-zone from remote sensing data. Revista Brasileira de Ciência do Solo, v.37, p.596-603, 2013.

Biudes, M. S.; Machado, N. G.; Danelichen, V. H. M.; Souza, Maísa C.; Vourlitis, G. L.; Nogueira, J. S. Ground and remote sensing-based measurements of leaf area index in a transitional forest and seasonal flooded forest in Brazil. International Journal of Biometeorology, v. 58, p.11811193, 2013.

Catian, G.; Scremin-Dias, E.; Pott, A. Reproductive phenology of Polygonum hispidum Kunth and P. punctatum Elliott (Polygonaceae), in response to the flooding cycle in the Pantanal, Brazil. Boletim do Museu Paraense Emílio Goeldi. Ciências Naturais, v. 12, p. 197-207, 2017. 
Chen, D. H. J.; Jackson, T. Vegetation water content estimation for corn and soybeans using spectral indices derived from MODIS near-and short-wave infrared bands. Remote Sensing of Environment, v.98, p.225-236, 2005.

Collares, G. L.; Reinert, D. J.; Reichert, J. M; Kaiser, D. R. Qualidade física do solo na produtividade da cultura do feijoeiro num Argissolo. Pesquisa agropecuária brasileira, v.41, p. 1663-1674, 2006.

Coringa, E. A. O.; Couto, E. G.; Perez, X. L. O.; Torrado, P. V. Atributos de solos hidromórficos no Pantanal Norte Matogrossense. Acta Amazonica, v. 42, p.19-28, 2012.

Couto, E.G.; Oliveira, V. The Pantanal of Mato Grosso: Ecology, biodiviersity and sustainable management of a large neotropical seasonall wetland. Sofia: Pensoft. The Soil Diversity of the Pantanal, p. 40-64. 2010.

Cremon, C.; Longo, L.; Mapeli, N. C.; Silva, L. A. M.; Silva, W. M. Determinação da umidade de diferentes solos do Pantanal Matogrossense via micro-ondas e método padrão. Revista Agrarian, v.7, n.24, p.280-288, 2014.

Fernandes, F.A.; Fernandes, A.H.B.M.; Soares, M. T. S.; Pellegrin, L.A.; Lima, I.B.T. Update Map of Soils of the Pantanal lowlands for the Brazilian System of Soil Classification. Comunicado Técnico 61 - Brasília-DF: Embrapa Pantanal, Corumbá-MS, 6 p, 2007.

Ford, T. W.; Quiring, S. M. Comparison of Contemporary in Situ, Model, and Satellite Remote Sensing Soil Moisture with a Focus on Drought Monitoring. Water Resources Research, v.55, p.1-18, 2019.

Gao B. NDWI - A normalized difference water index for remote sensing of vegetation liquid water from space, Remote Sensing of Environment, v.58, p.257-266, 1996.

Gevaerd, R.; Freitas, S. R.; Longo, M.; Moreira, D. S.; Silva Dias, M. A. F.; Silva Dias, P. L. Estimativa operacional da umidade do solo para iniciação de modelos de previsão numérica da atmosfera. Parte II: Impacto da umidade do solo e da parametrização de cumulus na simulação de uma linha seca. Revista Brasileira de Meteorologia, v.21, p.74-88, 2006.

Huete, A. R. A soil-adjusted vegetation index. Remote Sensing of Environment, v.25, p.295-309, 1988.

Huete, A. R.; Liu, H. Q.; Batchily, K.; Leeuuwen, W. Van. A Comparison of Vegetation Indices over a Global Set of TM Images for EOS-MODIS. Remote Sensing of Environment, p.440-451, 1997.

Lopez Garcia, M. J.; Caselles, V. Mapping burns and natural reforestation using thematic mapper data. Geocarto International, v.6, p.31-37, 1991.

Machado, N. G.; Biudes, M. S.; Querino, C. A. S.; Danelichen, V. H. M.; Velasque, M. C. S. Seasonal And Interannual Pattern Of Meteorological Variables In Cuiabá, Brazil. Revista Brasileira de Geofísica, 33(3), p.1-23, 2015. 
Masek, J.G., Vermote, E.F., Saleous N.E., Wolfe, R., Hall, F.G., Huemmrich, K.F., Gao, F., Kutler, J., And Lim, T-K. A Landsat surface reflectance dataset for North America, 1990-2000. IEEE Geoscience and Remote Sensing Letters 3(1): 68-72, 2006.

Mcfeeters, S. K. The use of Normalized Difference Water Index (NDWI) in the delineation of open water features, International Journal of Remote Sensing, v.17, p.1425-1432, 1996.

Miller, J. D.; Thode, A. E. Quantifying burn severity in a heterogeneous landscape with a relative version of the delta Normalized Burn Ratio (dNBR). Remote Sensing of Environment, v.109, p.66-80, 2007.

Nobre, C. A.; Fisch, G., Rocha, H. R.; Lyra, R. F. F.; Rocha, E. P.; Costa, A. C. L.; Ubarana, V. N. Observations of the atmospheric boundary layer in Rondônia. In: Gash, J. H. C.; Nobre, C.A.; Roberts, J.M.; Victoria, R.L. Amazonian Deforestation and Climate, p. 413-424, 1996.

Peng, J.; Loew, A.; Merlin, O.; Verhoest, N. E. C. A review of spatial downscaling of satellite remotely sensed soil moisture. Reviews of Geophysics, v.55, p.341-366, 2017.

Pereira, L. E.; Amorim, G.; Grigio, A. M.; Paranhos Filho, A. C. Análise Comparativa entre Métodos de Índice de Água por Diferença Normalizada (NDWI) em Área Úmida Continental. Anuário do Instituto de Geociências, v.41, p.654-662, 2018.

Rouse J. W.; Haas Jr, R. H.; Schell J. A.; D. W. Deering, Monitoring vegetation systems in the Great Plains with ERTS. Remote Sensing Center, NASA SP-351 I, p.309-317, 1973.

Qi, J.; Chehbouni, A.; Huete, A. R.; KERR, Y. H. Modified Soil Adjusted Vegetation Index (MSAVI). Remote Sensing of Environment, v.48, p.119-126, 1994.

Sakamoto, T.; Nguyen, N. V.; Kotera, A.; Ohno, N.; Ishitsuka, N.; Yokozawa, M. Detecting temporal changes in the extent of annual flooding within the Cambodia and the Vietnamese Mekong Delta from MODIS time-series imagery, Remote Sensing of Environment, v.109, p.295313, 2007.

Scott, C.; Bastiaanssen, W. G. M.; Ahmad, M. Mapping root zone soil moisture using remotely sensed optical imagery. Journal of Irrigation and Drainage Engineering, v.129, p.326-335, 2003.

SEPLAN - Secretaria de Estado de Planejamento e Coordenação Geral (Mato Grosso) Unidades climáticas do estado de Mato Grosso. Cuiabá, MT: 2001. A021p.

Serrano, L.; Ustin, Sl.; Roberts, Da.; Gamon, Já.; Penuelas, J. Deriving water content of chaparral vegetation from AVIRIS Data. Remote Sensing of Environment, v.74, p.570-581, 2000.

Willmott, C. J.; Robeson, S. M.; Matsuura, K. Short Communication A refined index of model performance. International Journal of Climatology, v.32, p.2088-2094, 2012. 


\section{Authorship Contribution}

\section{1 - Victor Hugo de Morais Danelichen}

Pós-doutor em Física Ambiental

danelichen@fisica.ufmt.br - http://orcid.org/0000-0003-4791-3301

Contribution: Investigation, Methodology, Writing - Original draft, Formal Analysis

\section{2 - Osvaldo Alves Pereira}

Doutor em Física Ambiental

osvaldoalvesfu@gmail.com - http://orcid.org/0000-0002-2159-4851

Contribution: Data curation, Conceptualization

3 - Marcelo Sacardi Biudes

Pós-doutor em Ciências Ambientais

marcelo.biudes@gmail.com - http://orcid.org/0000-0002-0795-8946

Contribution: Writing - Review \& Editing

\section{4 - José de Souza Nogueira}

Doutor em Ciências

nogueira@ufmt.br- http://orcid.org/0000-0003-2504-7924

Contribution: Supervision, Visualization

\section{How to quote this article}

DANELICHEN, V. H. M.; PEREIRA, O. A.; BIUDES, M. S.; NOGUEIRA, J. S. Assessment of spectral indexes for estimating soil water content in the Brazilian Pantanal. Ciência e Natura, Santa Maria, v. 43, e48, p. 1-18, 2021. DOI 10.5902/2179460X42724. Available from: https://doi.org/10.5902/2179460X42724. Accessed: Month Abbreviated. day, year. 